${ }^{9}$ Oster P, Arab L, Schellenberg B, Heuck CC, Mordasini R, Schlierf G. Blood pressure and adipose tissue linoleic acid. Res Exp Med (Berl) $1979 ; 175: 287-91$.

10 Böttcher CJF, Woodford FP. Lipid and fatty-acid composition of plasma lipoproteins in cases of aortic atherosclerosis. Fournal of Atherosclerosis Research 1961; 1:434-43.

1 Kingsbury KJ, Brett C, Stovold R, Chapman A, Andersson J, Morgan DM. Abnormal fatty acid composition and human atherosclerosis. Postgrad Med f 1974;50:425-40.

12 Kirkeby K, Nitter-Hauge S, Bjerkedal I. Fatty acid composition of adipose tissue in male Norwegians with myocardial infarction. Acta Med Scand 1972;191:321-4

13 Oliver MF. Dietary prevention of coronary heart disease: the role of essential fatty acids. In: Gotto AM Jr, Smith LC, Allen B, eds. Atherosclerosis V. New York: Springer-Verlag, 1980:235-43.
14 Holman RT. The ratio of trienoic: tetraenoic acids in tissue lipids as a measure of essential fatty acid requirement. F Nutr 1960;70:405-9.

15 Gudbjarnason S, Öskarsdöttier G, Doell B, Hallgrimsson J. Myocardia membrane lipids in relation to cardiovascular disease. In: Manninen V, Halonen PI, eds. Advances in Cardiology. Basle: Karger, 1978:130-44.

is Gudbjarnason S. Pathophysiology of long-chain polyene fatty acids in heart muscle. Nutr Metab 1980;24, suppl 1:142-6.

1: Gershfeld NL. Selective phospholipid adsorption and atherosclerosis. Science 1979;204:506-8.

18 Deby-Dupont G, Ducarne H, Lefevre A, Deby C, Lennes G, Goutier R. Recherches sur les relations entre acides gras polyinsaturés et accidents vasculo-cardiaques. Acta Cardiol 1980;2:83-91.

(Accepted 13 fuly 1982)

\title{
Arterial hypertension developing 10 years after radiotherapy for Wilms's tumour
}

\author{
OLLI KOSKIMIES
}

\begin{abstract}
Three patients developed arterial hypertension more than 10 years after receiving irradiation for Wilms's tumour. Scattered radiation appeared to have caused changes in the remaining kidney which were not severe enough to inhibit compensatory hypertrophy but which produced a rise in blood pressure at a later date. Since arterial hypertension appears to be a delayed complication of radiotherapy which is easily detected and controlled and can occur at any age long-term surveillance after successful treatment of malignant tumours in childhood is necessary.
\end{abstract}

\section{Introduction}

An increasing number of children with malignant diseases can now be cured or have their lives prolonged substantially by surgery, cytostatic drugs, and ionising radiation. The last two methods of treatment in particular are known to have many side effects, some appearing immediately and others only several years after treatment. Many organs are known to be adversely affected by radiation. The effects on the kidney have been graded by Luxton ${ }^{1}$ as follows: acute and chronic radiation nephritis, asymptomatic proteinuria, benign arterial hypertension, and malignant arterial hypertension.

In this paper I describe three patients who first developed arterial hypertension more than 10 years after irradiation treatment for Wilms's tumour. These findings emphasise the necessity of long-term surveillance of patients with successfully treated malignancies in childhood.

\section{Case reports}

CASE 1

In 1959 a girl aged 2 years 7 months was admitted with a history of haematuria and a palpable tumour on the right upper part of her abdomen. On admission haematuria and proteinuria were both

Children's Hospital, University of Helsinki, Helsinki, Finland OLLI KOSKIMIES, MD, lecturer in paediatrics present, and her systolic blood pressure was $105 \mathrm{~mm} \mathrm{Hg}$. A right nephrectomy was performed and a large tumour removed subradically. The tumour, which originated in the right kidney, had dislocated the liver, extended to the left side and infiltrated the renal vein and vena cava. Histological examination showed an undifferentiated nephroblastoma. During the operation $50 \mathrm{mCi}$ of radioactive gold were instilled into the space of the extirpated right kidney. Postoperatively, irradiation of 4073 rads was given to the right upper abdominal quadrant (table).

When the child was 3 years old a metastasis in the right lower pulmonary lobe was detected and a lobectomy performed. Postoperatively, irradiation of 3650 rads was given to the right lower chest. At the time of the operation her blood pressure was $105 / 60 \mathrm{~mm} \mathrm{Hg}$. She was followed up at the outpatient department until the age of 7 years. During this period her blood pressure was well within normal limits.

In 1974, at the age of 17 years, she was admitted with proteinuria and arterial hypertension, which had been detected by the school physician during a routine examination. She was small in stature (height $152 \mathrm{~cm}$, weight $53 \mathrm{~kg}$ ) with underdevelopment of the right side of the chest and the right breast. Her blood pressure was 160/120 $\mathrm{mm} \mathrm{Hg}$. An overnight urine specimen gave a urinary osmolality of $959 \mathrm{mmol} / \mathrm{kg}$ (959 mosmol $/ \mathrm{kg}$ ); protein and cell excretions were within normal limits. Sporadic urine analyses showed intermittent protein up to $5 \mathrm{~g} / 1$ and at times an increased number of leucocytes. Her haemoglobin concentration was $13 \mathrm{~g} / \mathrm{dl}$ and serum creatinine $55.7 \mu \mathrm{mol} / 1(0.63 \mathrm{mg} / \mathrm{dl})$. Intravenous pyelography showed the left kidney to be compensatorily hypertrophied as it was $>2$ SD above the mean in length. There was no evidence of coarctation of the aorta or intracranial processes. Serum electrolyte concentrations, calcium and phosphorus, thyroid function, and urinary catecolamine excretion were found to be normal, and there was no family history of hypertension. As no cause other than radiation injury to the remaining kidney was found treatment with reserpine was started. Blood pressure control was adequate, diastolic pressure being well below $95 \mathrm{~mm} \mathrm{Hg}$.

\section{CASE 2}

In 1960 an 11-month-old girl presented with a three-month history of tiredness and lack of appetite. She was admitted because there was palpable resistance in the left kidney area and her blood pressure was $220130 \mathrm{~mm} \mathrm{Hg}$. A left nephrectomy was performed and a partially undifferentiated nephroblastoma originating in the left kidney removed. Postoperatively, she received irradiation to the left upper abdominal quadrant and actinomycin D stosstherapy (table). After the operation her blood pressure fell to $110 / 80 \mathrm{~mm} \mathrm{Hg}$ and remained at that level during the follow-up period. She was admitted every 
three months for a year for actinomycin D stosstherapy and was thereafter seen at the outpatient department; follow-up was discontinued when she was 6 years old.

At the age of 8 she had measles and underwent an appendicectomy. At that time her blood pressure was $120 / 80 \mathrm{~mm} \mathrm{Hg}$. She was referred at the age of 14 years for further examination because of abdominal pain. She was of slender build (height $156 \mathrm{~cm}$, weight $37 \mathrm{~kg}$ ) with underdevelopment of the left side of the abdominal musculature, chest, and left breast and with a scoliosis towards the right side. $\mathrm{Her}$ blood pressure was $170 / 120 \mathrm{~mm} \mathrm{Hg}$; it had been measured several times during the two years before the examination and either the values had been normal or the diastolic value had been $90-95 \mathrm{~mm} \mathrm{Hg}$. Her urine analysis showed no abnormality with normal concentration capacity; her haemoglobin concentration was $13.1 \mathrm{~g} / \mathrm{dl}$ and ality and his systolic blood pressure was $100 \mathrm{~mm} \mathrm{Hg}$; the diastolic value was not systematically recorded. Follow-up was discontinued at the age of 8 years.

At the age of 13 he was referred again because of a scoliosis towards the right side. On examination his weight was $49 \mathrm{~kg}$, height $168 \mathrm{~cm}$; his left leg was $2 \mathrm{~cm}$ shorter than the right, and the abdominal and dorsal musculature and the vertebrae were underdeveloped. His blood pressure was $160 / 110 \mathrm{~mm} \mathrm{Hg}$. He had proteinuria (less than $1 \mathrm{~g} / \mathrm{l})$ and microscopic haematuria; his haemoglobin concentration was $12 \mathrm{~g} / \mathrm{dl}$ and serum creatinine $44.2 \mu \mathrm{mol} / 1(0.50 \mathrm{mg} / \mathrm{dl})$. There was no evidence of acute nephritis or vasculitis. Cystoscopy excluded local lesions in the urethra and bladder. Intravenous pyelography showed that his remaining kidney was more than 2 SD above the mean in length but normal in structure. Other causes of arterial hypertension

Patient data showing the development of arterial hypertension in three children with Wilms's tumour

\begin{tabular}{|c|c|c|c|c|c|c|}
\hline \multirow{3}{*}{$\begin{array}{l}\text { Case No } \\
(\text { (sex })\end{array}$} & \multicolumn{5}{|c|}{ Treatment of Wilms's tumour } & \multirow{3}{*}{$\begin{array}{c}\text { Final } \\
\text { follow-up } \\
\text { (age in years) }\end{array}$} \\
\hline & \multirow{2}{*}{$\begin{array}{c}\text { Age at } \\
\text { nephrectomy } \\
\text { (yrs) }\end{array}$} & \multirow{2}{*}{$\begin{array}{l}\text { Postoperative } \\
\text { irradiation } \\
\text { (rads) }\end{array}$} & \multirow{2}{*}{$\begin{array}{l}\text { Additional } \\
\text { treatment }\end{array}$} & \multicolumn{2}{|c|}{ Blood pressure reading: } & \\
\hline & & & & Preoperative & \multirow{2}{*}{$\frac{\text { Postoperative }}{105 / 60}$} & \\
\hline $1(\mathrm{~F})^{*}$ & $2 \% / 12$ & 4073 & $\begin{array}{l}\text { Local radioactive } \\
\text { gold }(50 \mathrm{mCi})\end{array}$ & $105 / ?$ & & $74 / 12$ \\
\hline $2(\mathrm{~F})$ & $11 / 12$ & 4937 & $\begin{array}{l}\text { Actinomycin D } \\
(60 \mu \mathrm{g} / \mathrm{kg} \text { for } \\
5 \text { days } 4 \\
\text { times } / \mathrm{yr})\end{array}$ & $220 / 130$ & $110 / 80$ & $6 \%$ \\
\hline \multirow[t]{2}{*}{$3(\mathrm{M})$} & $28 / 12$ & 3648 & $\begin{array}{c}\text { Actinomycin } D \\
(80 \mu \mathrm{g} / \mathrm{kg} \text { for } \\
5 \text { days } 10 \\
\text { times } / 2 \text { yrs })\end{array}$ & $170 / 120$ & $120 / 80$ & $8^{11 / 12}$ \\
\hline & \multicolumn{5}{|c|}{ Findings $11-15$ years after treatment for Wilms's tumour } & \\
\hline $\begin{array}{l}\text { Case No } \\
(\operatorname{sex})\end{array}$ & $\begin{array}{c}\text { Age at re- } \\
\text { examination } \\
(\text { yrs })\end{array}$ & $\begin{array}{l}\text { Clinical } \\
\text { findings }\end{array}$ & $\begin{array}{c}\text { Blood } \\
\text { pressure } \\
\text { (treatment) }\end{array}$ & $\begin{array}{c}\text { Serum } \\
\text { creatinine } \\
(\mu \mathrm{mol} / \mathrm{l})\end{array}$ & $\begin{array}{c}\text { Urine } \\
\text { analysis }\end{array}$ & $\begin{array}{l}\text { Findings at } \\
\text { intravenous } \\
\text { pyelography }\end{array}$ \\
\hline $1(\mathrm{~F})^{*}$ & $175 / 12$ & $\begin{array}{l}\text { Symptomless } \\
\text { proteinuria, } \\
\text { arterial } \\
\text { hypertension }\end{array}$ & $\begin{array}{c}160 / 120 \\
\text { (reserpine) }\end{array}$ & $55 \cdot 7$ & $\begin{array}{l}\text { No cells, } \\
\text { intermittent } \\
\text { proteinuria }\end{array}$ & $\begin{array}{l}\text { Compensatory } \\
\text { hypertrophy } \\
\text { of remaining } \\
\text { kidney }\end{array}$ \\
\hline $2(\mathrm{~F})$ & $14^{2 / 12}$ & $\begin{array}{l}\text { Recurrent } \\
\text { abdominal } \\
\text { pain, scoliosis, } \\
\text { arterial } \\
\text { hypertension }\end{array}$ & $\begin{array}{c}170 / 120 \\
\text { (propranolol) }\end{array}$ & $54 \cdot 8$ & Normal & $\begin{array}{c}\text { Compensatory } \\
\text { hypertrophy } \\
\text { of remaining } \\
\text { kidney }\end{array}$ \\
\hline $3(\mathbf{M})$ & $13^{7 / 12}$ & $\begin{array}{l}\text { Scoliosis, } \\
\text { proteinuria } \\
\text { and } \\
\text { haematuria, } \\
\text { arterial } \\
\text { hypertension }\end{array}$ & $\begin{array}{c}160 / 110 \\
\begin{array}{c}\text { (hydrochloro- } \\
\text { thiazide) }\end{array}\end{array}$ & $44 \cdot 2$ & $\begin{array}{c}\text { Microscopic } \\
\text { haematuria, } \\
\text { proteinuria }\end{array}$ & $\begin{array}{c}\text { Compensatory } \\
\text { hypertrophy } \\
\text { of remaining } \\
\text { kidney }\end{array}$ \\
\hline
\end{tabular}

* Other findings included: pulmonary metastases treated with lobectomy and irradiation ( 3650 rads) at age $3 \frac{1}{2}$ years. Conversion: SI to traditional units-Serum creatinine concentration: $1 \mu \mathrm{mol} / \mathrm{l} \approx 0.0113 \mathrm{mg} / \mathrm{dl}$.

serum creatinine $54.8 \mu \mathrm{mol} / 1(0.62 \mathrm{mg} / \mathrm{dl})$. Intravenous pyelography showed the right kidney to be normal; its length was approximately 2 SD above the mean. Other organic causes of arterial hypertension were excluded as in case 1 . In addition the peripheral renin activity was normal $(0.76 \mathrm{mmol} / \mathrm{ml} / \mathrm{h} ; 1.0 \mathrm{ng} / \mathrm{ml} /$ hour $)$. There was no family history of hypertension. The child was given propranolol, which moderately controlled her constantly raised blood pressure; later hydrochlorthiazide was added to the treatment. At the age of 16 she underwent an operation because of acute intestinal occlusion due to jejunal adhesions. Histological examination of the intestine showed changes of fibrous serositis, which may have been caused by the earlier radiotherapy. At that time her blood pressure was $115 / 90 \mathrm{~mm}$ $\mathrm{Hg}$ and she was taking the antihypertensive regimen as before.

\section{CASE 3}

In 1970 a boy aged 2 years 8 months presented with stomach pain after acute abdominal trauma. On admission he had a palpable tumour in the left upper abdomen and his blood pressure was $170 / 120 \mathrm{~mm} \mathrm{Hg}$. He had microscopic haematuria, and his blood urea concentration was $2.499 \mathrm{mmol} / 1(7 \mathrm{mg} / \mathrm{dl})$. The left kidney was surrounded by a haematoma and a left nephrectomy was performed. Nephroblastoma was diagnosed histologically. Postoperatively, his blood pressure fell to $120 / 80 \mathrm{~mm} \mathrm{Hg}$. Irradiation and actinomycin D stosstherapy were given (table). For two years he was admitted every three months for actinomycin D stosstherapy. Clinical examination showed no abnorm- were excluded as in case 1 . Because of his constantly raised blood pressure he was given hydrochlorathiazide. His mother also had raised blood pressure periodically but did not receive any medication.

\section{Discussion}

The arterial hypertension detected in these patients was considered to be of renal origin for several reasons. Firstly, ionising radiation is known to have unwanted effects on many organs, bringing about vascular changes (for example, pulmonary hypertension ${ }^{2}$ ) as well as parenchymal and vascular changes. ${ }^{13}$ The likelihood of renal damage due to direct radiation was supported by the gross macroscopic changes in the nearby organs. Secondly, two of the patients had proteinuria either alone or in combination with microscopic haematuria, which also indicated renal damage. Thirdly, other diseases known to cause secondary hypertension were excluded by clinical and laboratory investigations. Neither acute nephritis nor systemic disease were detected. Radiation-induced aortitis and subsequent coarctation of the abdominal aorta were excluded by determining blood pressure in the lower extremities. Thus scattered radiation appeared to have caused changes in the remaining kidney which were not severe enough to inhibit compensatory hypertrophy but which could cause a rise in blood pressure at a much later 
date. Renal biopsy was not performed for any of these patients because of the risk of damaging the remaining kidney. Renal arteriograms were not considered necessary as the blood pressure could be controlled successfully by low doses of antihypertensive agents. Apparently, these three cases belonged to the benign arterial hypertension category of Luxton. ${ }^{1}$

Shapiro $e t a l^{3}$ reported a case of Hodgkin's disease in which irradiation caused arterial hypertension to develop 10 years later. In their patient one kidney was shrunken owing to direct radiation damage and was the cause of the raised blood pressure. In all three patients reported in the present study, however, the remaining kidney was larger than average, thus showing that even a compensatorily hypertrophied kidney can be the cause of hypertension.

Because of the combination of various types of treatment, the number of children with malignant tumours who can be treated successfully is increasing. Every physician should therefore be aware of the side effects of such treatment and of the complications which can develop at a much later date. These case reports indicate that arterial hypertension is a delayed complication of radiotherapy which, however, is easily detected and controlled. If undetected it causes irreversible vascular damage. Thus, the traditional five-year follow-up after successful treatment of malignant disease is not long enough, as problems may arise much later at any age.

This study was supported in part by the Foundation for Pediatric Research and the Sigrid Jusélius Foundation.

Requests for reprints should be addressed to: Dr O Koskimies, Children's Hospital, Stenbäckinkatu 11, SF-00290 Helsinki 29, Finland.

\section{References}

${ }^{1}$ Luxton RW. Effects of irradiation on the kidney. In : Strauss MB, Welt LG, eds. Diseases of the kidney, 2nd ed, vol 2. Boston: Little, Brown and Co, 1971:1049-70.

2 Butler P, Chahal P, Hudson NM, Hubner PJB. Pulmonary hypertension after lung irradiation in infancy. $\mathrm{Br} M e d \mathcal{F} 1981 ; 283: 1365$.

${ }^{3}$ Shapiro AP, Cavallo T, Cooper W, Lapenas D, Bron K, Berg G. Hypertension in radiation nephritis. Report of a patient with unilateral disease, elevated renin activity levels, and reversal after unilateral nephrectomy. Arch Intern Med 1977;137:848-51.

(Accepted 14 Fuly 1982)

\title{
High dose of antacid (Mylanta II) reduces bioavailability of ranitidine
}

\author{
G W MIHALY，A T MARINO， L K WEBSTER，D B JONES，W J LOUIS，R A SMALLWOOD
}

\begin{abstract}
To investigate the effect of antacid on the bioavailability and disposition of ranitidine six healthy volunteers were studied on two occasions one week apart. In the first study they received ranitidine $150 \mathrm{mg}$ with $60 \mathrm{ml}$ water, and in the second study they received ranitidine $150 \mathrm{mg}$ plus $30 \mathrm{ml}$ of an aluminium/magnesium hydroxide mixture (Mylanta II) and $30 \mathrm{ml}$ water. Giving antacid reduced both the maximum plasma ranitidine concentration and the area under the curve by one-third; elimination of the drug was not changed.
\end{abstract}

Thus giving a high dose of antacid significantly diminished the bioavailability of ranitidine.

\section{Introduction}

The efficacy of the histamine $\mathrm{H}_{2}$-receptor antagonist ranitidine in the treatment of peptic ulceration is related to the plasma drug concentration achieved. ${ }^{1}$ Antacids are commonly prescribed with $\mathrm{H}_{2}$-receptor antagonists; in the case of cimetidine coadministration of antacid reduces bioavailability by one-third. ${ }^{23}$ The aim of the present study was to investigate the effect of antacid on the bioavailability and disposition of ranitidine.

Austin Hospital, Heidelberg, 3084, Melbourne, Victoria, Australia

G W MIHALY, PHD, senior research officer (National Health and Medical Research Council of Australia), gastroenterology unit

A T MARINO, BPHARM, pharmacist, department of pharmacy

L K WEBSTER, BSC, research assistant, gastroenterology unit

D B JONES, MB, MRCP, gastroenterology fellow

W J LOUIS, MD, FRACP, professor, clinical pharmacology

R A SMALLWOOD, MD, FRACP, director, gastroenterology unit

\section{Subjects, methods, and results}

Six healthy volunteers (three men, three women) aged 21-29 years and weighing $56-83 \mathrm{~kg}$ were each studied on two occasions a week apart. In the first study, after an overnight fast each subject received ranitidine as a $150 \mathrm{mg}$ tablet (Zantac) with $60 \mathrm{ml}$ water (control study) In the second study the ranitidine tablet was taken with $30 \mathrm{ml}$ of an aluminium/magnesium hydroxide mixture (Mylanta II; neutralising capacity $150 \mathrm{mmol}(5.5 \mathrm{~g})$ hydrochloric acid/30 ml) plus $30 \mathrm{ml}$ water (antacid study). On each occasion blood was sampled at intervals to 12 hours and urine to 24 hours and assayed as previously described.

The maximum plasma concentration and the time taken to reach it were obtained directly from each subject's plasma concentration-time profile. The area under the plasma concentration-time curve from

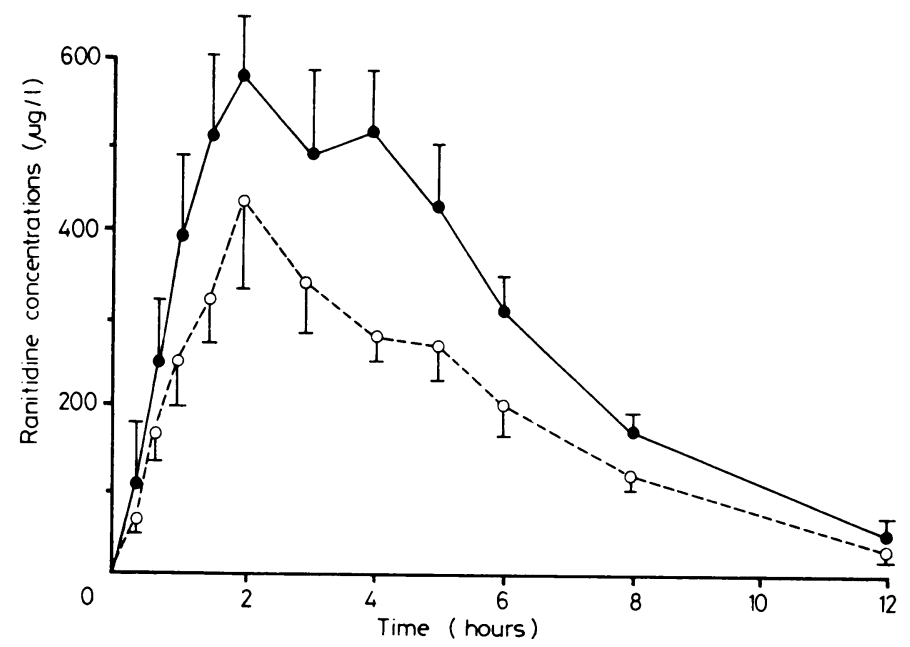

Mean \pm SEM plasma ranitidine concentrations $(n=6)$ after control ( and antacid ( $O$ - - $O$ ) studies, showing significant reduction in bioavailability with antacid. 